This is an electronic reprint of the original article. This reprint may differ from the original in pagination and typographic detail.

Author(s): Karjaluoto, Heikki; Jayawardhena, Chanaka; Leppäniemi, Matti; Pihlström, Minna

Title: $\quad$ How value and trust influence loyalty in wireless telecommunications industry

Year: $\quad 2012$

Version:

Please cite the original version:

Karjaluoto, H., Jayawardhena, C., Leppäniemi, M., \& Pihlström, M. (2012). How value and trust influence loyalty in wireless telecommunications industry.

Telecommunications Policy, 36(8), 636-649.

https://doi.org/10.1016/j.telpol.2012.04.012

All material supplied via JYX is protected by copyright and other intellectual property rights, and duplication or sale of all or part of any of the repository collections is not permitted, except that material may be duplicated by you for your research use or educational purposes in electronic or print form. You must obtain permission for any other use. Electronic or print copies may not be offered, whether for sale or otherwise to anyone who is not an authorised user. 


\title{
How value and trust influence loyalty in wireless telecommunications industry
}

\begin{abstract}
Despite making significant investments in enhancing the customer service experience, long-term customer loyalty remains an elusive dream for many service providers. Particularly in the telecommunications industry, switching providers even from within continuous contract relationships is easy and companies struggle to retain their customers. Trust and value are considered cornerstones of long-term relationships, so it is perhaps surprising that previous research on how relationship age and usage level actually affect value, trust and loyalty is inconclusive. The current research is set in the telecommunications services field and draws on a large-scale survey undertaken in Finland. The findings support the contention that perceived value relates positively to loyalty, and that trust mediates that relationship. Surprisingly, in the telecommunications industry, increasing relationship age and usage level strengthen neither value and loyalty nor the links between trust and loyalty. The results may be explained by the unique characteristics of the highly competitive mobile telecommunications sector, and confirm the view that "loyalty does not pay" without strategies that value long-term customers and thereby build trust with new customers.
\end{abstract}

Keywords: Perceived value, trust, loyalty, relationship age, usage level, wireless services 


\section{Introduction}

Customer loyalty is an important strategic objective of organizations, for loyal customers are usually willing to spend more and may serve as enthusiastic advocates for the organization (Harris \& Goode, 2004). Customer loyalty in continuous service settings is perhaps even more important. This assertion arises from the high levels of competition and the variety-seeking behavior of customers (Verhoef, 2003), organizations that provide continuous services (i.e., service that is delivered continuously and typically involves a contract) such as financial institutions (Bolton, Kannan, \& Bramlett, 2000), telecommunications companies (Johnson, Herrmann, \& Huber, 2006) and the like have few opportunities for differentiation and are faced with strong price competition in saturated markets.

Long-term customer loyalty remains an elusive dream for many organizations; indicating that there is still much to learn about the subject. For instance, the notions that loyal customers are less expensive to serve, are willing to pay higher prices for goods and services, and serve as strong advocates of the company and its offerings have been questioned (Reinartz \& Kumar, 2002).

Other scholars have called for more research on the links between the antecedents of loyalty and its nature (Agustin \& Singh, 2005; Dick \& Basu, 1994; Evanschitzky, Iyer, Plassmann, Niessing, \& Meffert, 2006; Oliver, 1997), and its relationship with customer profitability (Reinartz \& Kumar, 2002). While a number of prominent commentators (e.g., Hoffman, Novak, \& Peralta, 1999; Reichheld \& Schefter, 2000; Reynolds, 2000) emphasize the importance of trust and loyalty, empirical research into their dynamics 
remains in its infancy (Harris \& Goode, 2004; Srinivasan, Anderson, \& Ponnavolu, 2002; Stewart, 2003).

In response to these calls, our study examines the antecedents and moderators of loyalty in a continuous service setting, by empirically testing a service loyalty model linking perceived value, trust, and loyalty. Prior research demonstrates that perceived value (Sirdeshmukh, Singh, \& Sabol, 2002) and trust (Agustin \& Singh, 2005; Singh \& Sirdeshmukh, 2000) are instrumental in influencing customer loyalty. Additionally, we seek to extend the literature by addressing the following two issues: the first is whether the relationship age affects how value and trust influence loyalty and the second is if differences in the usage level affect how value and trust influence loyalty.

Literature on relationship age investigates how it influences the customer's evaluation of the relationship with an organization (Swann \& Gill, 1997) and its offerings (Kalwani \& Narayandas, 1995; Szmigin \& Bourne, 1998). There is also evidence that relationship age moderates the link(s) between satisfaction and cross-buying (Verhoef, Francis, \& Hoekstra, 2001); trust, payment equity, commitment and customer referrals, amount of the service purchased (Verhoef et al., 2002); and customer retention (Verhoef, 2003). In the majority of instances, the effects of satisfaction, trust and commitment on the various dependent variables are enhanced by relationship age, but there are conflicting views (e.g., Raimondo, Gaetano, \& Costabile, 2008; Verhoef et al., 2002). Most research on relationship age has been conducted in non-contractual settings and that on continuous services is limited, the work of Bolton (1998) being a notable exception. The latter provides evidence of a positive relationship between relationship age and satisfaction in telecommunications services. More research has been called for especially 
in the cellular market exploring samples exemplifying different relationships with the service provider (Gerpott, Rams, \& Schindler, 2001). As such, our examination of the moderating effects of relationship age on customer loyalty is timely and its focus on telecommunications services is justifiable.

Research examining the usage level of a service and its effect on service loyalty is sparse. According to Reichheld and Sasser (1990), long-term customers are more profitable to a company, because they spend more and are cheaper to maintain. In this context, it is important to investigate whether customers who spend more on a regular basis are more loyal to a service provider than customers who spend less. In this study, we investigate this question by examining the moderating effect of monthly expenditure on perceived value-trust and trust-loyalty links.

The remainder of this paper is structured as follows. The following section provides background information on the constructs under examination. There we also detail the formulation of our hypotheses, and present our conceptual model evaluating the role of the antecedents of customer loyalty in a continuous service setting. The subsequent section details the research methodology. Thereafter we present the analysis and results. Finally, the paper concludes with a discussion of study outcomes, implications for academics and practitioners, the limitations of the study and suggested directions for future research.

\section{Conceptual framework}

Figure 1 presents loyalty as a consequence of direct and indirect relationships with perceived value and trust. Loyalty, for its part, is presented as a multi-dimensional 
construct consisting of attitudinal and behavioral loyalty. In what follows, the rationale for the conceptual model is generalized, in part, from the theories and findings of frameworks of service (e.g., Cronin, Brady, \& Hult, 2000; Oliver, 1997; Parasuraman \& Grewal, 2000), specific studies of continuous service settings (Raimondo et al., 2008) and telecommunications. The constructs under consideration in this study and our rationale for linkages between individual concepts and the further details of theory on which we rely, are outlined below.

\section{$<$ Please insert Figure 1 about here $>$}

\subsection{Perceived value and its effect on trust}

As a construct, perceived value has attracted significant attention from marketing scholars in general, and some argue that the study of perceived value has dominated services literature (Cronin et al., 2000). Perceived value is based on equity theory and refers to customers' assessments of what is right, fair or deserved for the perceived cost of the offering (Bolton \& Drew, 1991). Perceived value has typically been defined as a trade-off between benefits and sacrifices.

Sanchez-Fernandez and Iniesta-Bonillo (2007) classify perceived value research into unidimensional and multidimensional models. The unidimensional view of value emphasizes price-related studies and means-end theories. The notion that perceived value is a multidimensional construct has long been recognized (Sheth, Newman, \& Gross, 1991a), and researchers over the years have attempted to delineate the various 
dimensions of value. One of the sub-streams of the multidimensional perceived value research highlights the two main dimensions, namely utilitarian and hedonic value.

Sheth et al. (1991a) propose a framework of consumption values to explain why consumers choose to purchase or use a brand. This framework has been applied in several studies since (e.g., Sweeney \& Soutar, 2001; Wang, Lo, Chi, \& Yang, 2004). Sweeney and Soutar (2001), basing their work on that of Sheth et al. (1991a), present four values: functional value related to performance/quality (here functional value), functional value relating to price/value for money (here monetary value), emotional value, and social value.

Functional value relates to effective task fulfillment, typically through utilitarian, physical or functional performance. In consumer behavior literature, effective task fulfillment has also been referred to as the output/input ratio; convenience; availability and ease of use (Holbrook, 1994). Functional value is considered two-dimensional consisting of quality and value for money (Sweeney \& Soutar, 2001). Whereas quality refers to "the utility derived from the perceived quality and expected performance of the product" (Sweeney \& Soutar, 2001, p.211). Price-related monetary value denotes perceptions of good value for money or low price compared to the alternatives (Sheth et al., 1991a). In the telecommunications sector, perceived monetary value is a key factor explaining both intention to use and usage level of mobile services (Kim, 2012). Emotional value is present when a product or service arouses feelings or produces an effect. Aesthetic pleasure and associations with earlier experiences, as well as play or fun enjoyed for its own sake are also credited with being able to generate emotional value (Holbrook, 1994; Sheth et al., 1991a). Sweeney and Soutar (2001, p.211) define social 
value as "the utility derived from the product's ability to enhance social self-concept". Social value therefore associates users of the service with a social group and includes such aspects as social image, identification, social self-concept, expression of personality and pursuit of class membership (Bearden \& Etzel, 1982; Bhat, Burkhard, O’Donnell, \& Wardlow, 1998). Social value is thus related to social approval and the enhancement of self-image (Bearden \& Netemeyer, 1999).

Trust is most often portrayed as the outcome of reflexive consideration of the ability of a firm or brand to meet set obligations (Doney \& Cannon, 1997). Therefore, trust is a central attribute in relationship initiation, formation, and maintenance in a variety of exchange contexts (Verhoef et al., 2002). In particular, it is suggested that service exchanges rely on trust owing to the intangible nature of services, which creates uncertainty and a perceived risk for the consumer during purchase and consumption (Berry, 1995; Crosby, Evans, \& Cowles, 1990).

Perceived value and trust have a direct positive association (Harris \& Goode, 2004; Singh \& Sirdeshmukh, 2000). Although research indicates that perceived value is affected by judgments of trust, thereby creating value through relational benefits obtained from the interaction with service providers (Sirdeshmukh et al., 2002), the more dominant view of perceived value and trust linkage supports the view that "trust is a key and central factor during exchange, after accounting for previously established antecedents, namely; perceived value..." (Harris \& Goode, 2004, p.150). In an online service context, the latter research finds that perceived value and trust link strongly, supporting the results of Singh and Sirdesmukh (2000). 
However, as Harris and Goode (2004) and Sirdeshmukh et al. (2002) note, more empirical research would be beneficial to examine the link between perceived value and trust in service contexts.

H1: Perceived value links positively to trust.

\subsection{Trust and loyalty}

There is no universal consensus on the definition of loyalty (Jacoby \& Chestnut, 1978; Oliver, 1999). Researchers argue that a meaningful measure of customer loyalty cannot omit the measurement of either attitude or behavior (Gwinner, Gremler, \& Bitner, 1998). By building upon and extending earlier work in conceptualizing loyalty, Oliver (1997, p.392) defines loyalty as "a deeply held commitment to rebuy or repatronize a preferred product or service consistently in the future, despite situational influences and marketing efforts having the potential to cause switching behavior". Oliver (1999) goes on to identify four different and sequential loyalty dimensions: cognitive, affective, conative and action loyalty. In this research we measure loyalty as a two-dimensional construct consisting of attitudinal and behavioral constructs, because, most of the loyalty literature supports a simplified two-dimensional view of customer loyalty (Dick \& Basu, 1994; Zeithaml, Berry, \& Parasuraman, 1996; Chaudhuri \& Holbrook, 2001;

Bandyopadhyay \& Martell, 2007) suggesting that both attitudinal and behavioral aspects are required to define loyalty. Nevertheless, in the structural model, loyalty is treated as a latent second order construct, because this paper focuses on estimating the mediating role of trust between value and loyalty. 
Research affirms trust to be the cornerstone of long-term relationships (Dwyer, Schurr, \& Oh, 1987; Verhoef et al., 2002) and a strong antecedent of customer loyalty (Garbarino \& Johnson, 1999; Sirdeshmukh et al., 2002). Prior studies are consistent in proposing that trust has a positive, direct and/or indirect effect on the various aspects of customer loyalty (Chaudhuri \& Holbrook, 2001; Lau \& Lee, 1999; Sirdesmukh et al., 2002). Chaudhuri and Holbrook (2001) propose that brand trust has a direct positive effect on both purchase loyalty and attitudinal loyalty. In positioning value, trust and loyalty in the conceptual model, we propose a value-trust-loyalty relationship in which trust is a mediator of value on loyalty. This is because when consumers receive, on an ongoing basis, a competent service from the service provider, they perceive that they are receiving a service of high value. This leads them to begin to trust the service.

It follows that perceived value would lead to more trust, and then loyalty. This argument is line with Chiou et al. (2010) and Morgan and Hunt (1994), who argue that trust acts as a mediator between loyalty and its antecedents. In addition, extant literature suggests that trust mediates the effects of quality, satisfaction, and loyalty (Aydin \& Özer, 2006; Gummerus, Liljander, Pura, \& van Riel, 2004).

H2: Trust mediates the effect of perceived value on customer loyalty

\subsection{The moderating effect of relationship age}

On a theoretical level, an examination of the moderating effects of relationship age might suggest explanations for conflicting findings with regard to the effect of 
relational constructs on relationship performance (Doney \& Cannon, 1999; Gruen, Summers, \& Acito, 2000; Verhoef et al., 2002). Relationship age may affect a customer's evaluation of the relationship with the service provider. The age of the relationship is positively related to confidence in one's evaluations of the partner (Swann \& Gill, 1997). Other researchers extend this view and suggest that buyer-seller relationships progress through different phases over the lifetime of the relationship. In this context, Dwyer et al. (1987) show that each relationship phase represents a transition of how the parties regard one another. They go on to argue that in the different phases, different variables are important in explaining the success of relationships.

In the early stages of a relationship, it is difficult for customers to base their behavior on the evaluation of their experience. This is because at that stage customers do not have much experience with the company (Verhoef et al., 2002), and their impressions lack depth or richness (Swann \& Gill, 1997). However, empirical results are not unequivocal on whether influence on loyalty is dependent on relationship age or not, or whether trust actually grows or diminishes as the customer relationship matures over the years.

Grayson and Ambler (1999) report that trust positively affects business-tobusiness clients' use of services in short-term relationships, and Garbarino and Johnson (1999) show that trust influences repurchase intentions and commitment (attitudinal loyalty) only for consistent subscribers, whereas these effects are not significant for occasional customers in a non-contractual theatre setting. Non-significant influences are also reported. For instance, Verhoef et al. (2002) do not find a reliable interaction between trust and relationship age in determining customer referrals and the amount of 
insurance services purchased. In the telecommunications industry, subscription duration has even been found to influence the likelihood of switching providers (Kim \& Yoon, 2004). More recently, Raimondo et al. (2008) do not find a reliable interaction between trust and relationship age in determining customer loyalty in mobile services. Nevertheless, the notion that long-term customers base their loyalty on trust perceptions is consistent with the loyalty literature (Oliver, 1999).

H3: Relationship age moderates the positive relationships between perceived value and trust, and trust and loyalty. Specifically, relationship age enhances the perceived value-trust and trust-loyalty positive relationships.

\subsection{The moderating effect of usage level}

Research holds that long-term customers are more profitable to a company than short-term customers (Reichheld \& Sasser, 1990; Reichheld, 1996). This is because the revenue they generate for the company is usually higher and the costs of maintaining the relationship usually lower. The discussion of whether profitability is related to loyalty is inconclusive (Oliver, 1997, p.404), and views differ on whether loyalty and profitability are positively related (Reinartz \& Kumar, 2000; 2002). In short, as profitability is a function of revenues and costs, an examination of the level of usage of a service, and its moderating effect on the antecedents of loyalty, should offer important insights into the moderating role on the perceived value-trust-loyalty links of revenue derived from a customer's monthly expenditure on a service. 
Behavioral loyalty is commonly measured through purchase volume or monetary expenditure. In the long-term, businesses also apply the RFM format to measure recency, frequency and monetary value of the service use in order to provide a simple estimate of the lifetime value of their customers. In this study, the information on expenditure is collected from customers, based on their own estimation of average monthly expenditure.

To summarize, the positive relationship between expenditure and loyalty has been confirmed in many industries (Knox \& Denison, 2000) and in the services sector specifically (Reichheld \& Sasser, 1990; Reichheld, 1996). In the telecommunications sector, literature supports the notion that customers with low and moderate expenditure levels rate good value for money more than the high expenditure group, who value support services above all else (Lee, Lee, \& Feick, 2001). A recent study conducted in the telecommunications sector (Keramati \& Ardabili, 2011) finds that the amount of service usage, with monthly expenditure being the most significant predictor, positively influences customer retention. The former study confirms that low-level users are more likely to change their mobile operator more often than high-level users. Thus, in line with prior literature (Ahn, Han, \& Lee, 2006) usage level is a strong predictor of customer retention in the telecommunications sector. On this basis, we propose

H4: Expenditure moderates the positive relationships between perceived value and trust, and trust and loyalty. Specifically, expenditure enhances the perceived valuetrust and trust-loyalty positive relationships.

\section{Method}

\subsection{Sample}


The sample of respondents for the survey was drawn from the database of the Finnish Population Information System. Questionnaires containing the measures, accompanied by a cover letter and a pre-paid return envelope were mailed to 6000 respondents, who were selected from the database to be representative in terms of gender, age and place of residence. The cover letter explained the purpose of the study, provided assurances that responses would remain confidential, and thanked the prospective participant for their assistance. After the initial section, respondents completed measures pertaining to trust, value, and loyalty, and finally, respondents answered demographic questions. To improve response rates, participation was encouraged by inclusion in a prize draw for a mobile phone. No reminder letters were mailed to non-respondents. The data were collected over a period of four weeks.

The respondents are customers of the eight mobile phone service providers in Finland with a continuous monthly contract (note: the level of mobile phone subscription in Finland is $100 \%$ and $83 \%$ of services used are paid for through billing after use). In other words, these customers pay a monthly and usage-based fee to a mobile operator according to either the rate plan they have chosen or actual usage. In the case of the former, plans tend to be tailored to different usage patterns, while for the latter, the monthly fee varies by usage level and customers also pay an initial fee to purchase the handset. Around 10\% of the contracts are pre-paid or 'pay-as-you-go' (Finnish Communications Regulatory Authority, 2011). In addition, customers can choose to subscribe to the service and have the option to continue or discontinue the service on a monthly basis. In addition, since 2003 customers have had the option of changing service provider without losing their mobile phone number. 
The competitive landscape in the Finnish mobile operator industry is fierce but stable. Three telecommunications companies, namely Elisa, TeliaSonera, and DNA, dominate the Finnish mobile operator markets. Elisa has the largest market share (39\%), followed by TeliaSonera (36\%) and DNA (23\%). In 2010, 610,000 mobile phone numbers were transferred from one operator to another (Finnish Communications Regulatory Authority, 2011).

We received 1,385 usable responses resulting in a reasonable response rate of $23.1 \%$. The sample is female dominated $(56 \%)$, and a majority of the respondents are from the 35-49 (31\%) and 50-64 (36\%) age groups. Approximately one third of those sampled have been a customer of their current mobile operator for between two and four years $(35 \%)$ and one third of the sample have been with their operator for over four years (31\%). Forty-four percent of the respondents report having a mobile phone bill of 21-40 EUR per month while $40 \%$ of respondents report that their mobile phone bill is less than 20 EUR per month. The demographic profile of the sample is presented in Table 1.

\section{<Please insert Table 1 about here>}

The number of missing values accounts for less than one percent of the total number of values. Little's MCAR test (Little \& Rubin, 1987) indicates that these values were missing completely at random ( $p \geq .05)$. We therefore conclude that that the missing values are not a result of a hidden systematic pattern and no imputation methods could be applied to replace them (Hair, Anderson, Tatham, \& Black, 1998). We apply a regression imputation method since it predicts the missing value of a variable based on its 
relationship with other variables, thereby ensuring that the replacement value is consistent with the existing relationship structure in the data set (Hair et al., 1998).

Following the recommendations of Armstrong and Overton (1977), the responses of early and late respondents were compared to gauge non-response bias. No significant differences $(p \leq .05)$ were found among any of the variables or factors used in later analysis. To gauge the representativeness of sample, it was compared to the general population of Finland in terms of gender, age, place of residence and mobile phone subscription. No significant differences were found (see Table 1). Therefore, the sample is representative of Finnish mobile phone users.

\subsection{Measures}

The questionnaire was designed with measures of the relevant constructs based on scales taken from previous research. We made some changes, consistent with the specific characteristics of the industry surveyed and our research setting. A number of academic colleagues (four marketing professors) and three specialists (representing the mobile operators) evaluated the items to establish the prima facie validity of the constructs. The use of experts as judges of a scale's domain is common in marketing (e.g., Babin \& Burns, 1998; Sweeney \& Soutar, 2001; Zaichowsky, 1985). After a number of amendments to item wording, question order and layout, the modified survey instrument was then pretested on 33 university students. It was subsequently agreed that there were no substantive concerns and the questionnaire was deemed suitable for final data collection. The items used in the questionnaire are shown in Appendix A. 
Building on the work of Sheth et al. (1991a; 1991b), Sweeney \& Soutar (2001) developed the PERVAL model involving four, distinct value dimensions: emotional, social, quality/performance and price/value for money. Consequently, the perceived value scale used in the current study is constructed to measure divergent dimensions of consumers' consumption values. Emotional value is measured by four items adapted from Sweeney and Soutar (2001). Our questionnaire items relate to the evaluation of the emotional aspects of the service of a person's current mobile operator (e.g., "The service of my mobile operator...is one that I would feel relaxed about using"). Social value is a three-item construct taken from Wang et al. (2004). The items request respondents' evaluations of the utility derived from the service's ability to enhance social self-concept (e.g., "The service of my mobile operator... would improve the way I am perceived"). The functional value measures were drawn from Wang et al. (2004). Guided by the view of Sheth et al. (1991a; 1991b), the items for capturing functional value were designed to evaluate whether a service is able to fulfill its functional purpose (e.g., "My mobile operator always delivers superior service"). The three monetary value measures were drawn from Sweeney and Soutar (2001). All value items are rated on seven-point Likerttype scales ranging from strongly disagree to strongly agree.

Perceived trust is measured with six items drawn from Chiou and Droge (2006). The items included honesty, reliability, responsibility, and motives/intentions. The sevenpoint Likert-scales were anchored by strongly disagree / strongly agree.

The loyalty scale is designed to measure both attitudinal and behavioral aspects of loyalty. In measuring attitudinal loyalty, we include the cognitive, affective and conative aspects of Oliver's $(1997 ; 1999)$ four-stage loyalty framework. Items measuring 
attitudinal loyalty are derived from the study undertaken by Harris and Goode (2004). To measure behavioral loyalty, the scales developed by Zeithaml et al. (1996) and Garbarino and Johnson (1999) (see also Evanschitzky \& Wunderlich, 2006) are utilized. Our behavioral loyalty scale contains two items involving repurchase intentions adopted from Zeithaml et al. (1996). In addition, we adopt one item commonly used in customer loyalty research as an indicator of the customer patronage intention (Garbarino \& Johnson, 1999). The scale also features two items relating to recommendations revised from Zeithaml et al. (1996), and in line with the former, we measure the customers' selfreported recommendation behavior rather than their recommendation intention. All loyalty items are rated on seven-point Likert-type scales ranging from strongly disagree to strongly agree. Relationship age is operationalized following the methods of the study by Raimondo et al. (2008), by asking "Please indicate how long you have been a customer of your current mobile operator." The item is measured on a scale ranging from under six months, six to 12 months, one to two years, two to four years, over four years. Most customers (69.6\%) have been customers of their current carrier for over two years. Only $8.1 \%$ report being in their current supplier relationship for less than 12 months.

The monthly expenditure construct is operationalized by asking the question "How large on average is your mobile phone bill in a month?" The item is measured on a scale ranging from under $20 \mathrm{EUR}, 21$ to $40 \mathrm{EUR}, 41$ to $70 \mathrm{EUR}$, and over $71 \mathrm{EUR}$. A total of $40 \%$ of the respondents reported having a monthly bill of less than 20 EUR, whereas $44 \%$ had an average bill of between 21 and 40 EUR. Customer income is operationalized as a six item scale. The majority $(59.1 \%)$ of the respondents have a monthly gross income between 1001 and 2500 EUR. 
The survey was administered in Finnish. Therefore, all the scales were professionally translated through back-translation to ensure conceptual equivalence (e.g., Douglas \& Craig, 1983; Mullen, 1995).

\section{Results}

We apply PLS structural equation modeling (Fornell \& Cha, 1994) to test the hypotheses. Specifically, we employ SmartPLS 2.0 (Ringle, Wende, \& Will, 2005), which permits the simultaneous testing of hypotheses while enabling single and multi-item measurement and the use of both reflective and formative scales (Fornell \& Bookstein, 1982). The PLS estimation approach is a component-based structural equation modeling technique that offers advantages over covariance based approaches when an interacting model contains a mix of reflective and formative type measures (Chin, 1998). In this study, both relationship age and usage level are formative measures. Where at least one component of the interacting variable is formative, the pairwise multiplication of indicators is not optimal. Since formative indicators are not assumed to reflect the same underlying construct, the product indicators will not necessarily tap into the same underlying interaction effect (Chin, Marcolin, \& Newsted, 2003). As a distribution-free method, PLS has fewer constraints and statistical specifications than covariance-based techniques (Hennig-Thurau, Henning, \& Sattler, 2007).

\subsection{Exploratory phase}


The scales are first subjected to a series of exploratory factor analyses. Principal axis-factoring with varimax rotation reveals that the perceived value scale has four dimensions, which, in line with the theory (Sweeney \& Soutar, 2001; Wang et al., 2004), relate to social value, emotional value, monetary value and functional value. The factor analysis explains $78 \%$ of the variance. Two items (“...is one that I would enjoy” and "The offerings of my mobile operator make me feel confident") had high cross-loadings and have been dropped from further analysis. Regarding trust, in line with theory (Chiou \& Droge, 2006), only one factor of the six items emerges with high factor loadings (>.80). The exploratory factor analysis with the loyalty items reveals two loyalty dimensions, which relate to attitudinal and behavioral loyalty. The two factor solution explains $64 \%$ of the variance. In line with theory, the first factor exhibits high loadings for five variables relating to attitudinal aspects of loyalty. The second factor has high loadings of five items relating to behavioral loyalty.

Next, we treat value and loyalty as second order latent constructs and evaluate the hypothesis analyzing the structural model.

\subsection{Confirmatory phase}

Within the confirmatory phase, first, we test a direct effects model (excluding the moderating effect of relationship age and usage level) and, second an interaction model (including moderating effects) on the whole sample. The purpose of this approach is to test whether adding the interaction terms improves the explanatory power of the model. 


\subsubsection{Assessment of measurement (outer) model}

Following Homburg and Pflesser (2000), we calculate composite reliabilities, coefficient alphas and average variance extracted for reflective scales composed of more than two items. As can be seen from Table 2, average variance extracted (AVE), composite reliabilities (CR), and internal consistency reliabilities (Cronbach's $\alpha$ ) for the constructs used in the model meet the respective $0.50,0.60$ and 0.70 thresholds.

\section{$<$ Please insert Table 2 about here $>$}

Discriminant validity is assessed both at the item and at the construct level. Fornell and Larcker's (1981) test shows that the AVE for each of the constructs is greater than the squared correlations for all pairs of constructs (see Table 2). With respect to item discriminant validity, an inspection of indicator cross-loadings reveals that all indicators load at their highest with their respective construct and that no indicator loads higher on other constructs than on its intended construct. It is therefore safe to assume item discriminant validity. At the construct level, the comparison of the square root of each reflective construct's AVE (Table 2) and the latent variable correlations (Table 3) (Chin, 1998) suggests that there is satisfactory discriminant validity (Cool, Dierickx, \& Jemison, 1989).

\section{<Please insert Table 3 about here $>$}

\subsubsection{Common method bias}

There is a potential for common method bias with all self-reported data (Podsakoff, MacKenzie, Lee, \& Podsakoff, 2003). We apply a procedural remedy at the 
data collection stage to protect the identities of the respondents. Further, item ambiguity is reduced and the items are mixed in the questionnaire. We then conduct statistical analysis to assess the severity of common method bias. First, we examine common method variance bias with Harman's (1967) one factor test. Results show that measurement model factors are present and the maximum covariance explained by one factor is $19.7 \%$, indicating that common method bias is not a likely contaminant of our results. Second, in the data analysis stage, following Podsakoff et al. (2003) and Liang, Saraf, Hu, and Xue (2007), we ran a PLS model with a common method factor with indicators that included all the principal constructs, and went on calculate each indicator's variances as substantively explained by the principal construct. The results of the analysis show that average variance substantively explains variance of the indicators (.64), while the average method based variance is .029. It is also apparent that most method factor coefficients are not significant. Given the magnitude and the insignificance of method variance, we would argue that common method bias is unlikely to be of serious concern to this study.

\subsubsection{Assessment of the structural (inner) model}

In order to estimate paths between the latent variables, a path-weighting scheme is utilized, as it is the only weighting scheme that expressly considers the conceptual model directions of the causal relationships between exogenous and endogenous variables (Chin, 1998). Following common conventions, the abort criterion for the iterative estimation process is a change in the estimated values of just $10^{-5} \%$ between two iterations. In order to determine the significance of each estimated path, a standard 
bootstrapping procedure is applied with 500 re-samples consisting of the same number of cases as in the original sample (Yung \& Bentler, 1996).

As stated earlier, we test a direct effects model (excluding the moderating effect of relationship age and usage level, referred to as Model 1) and a second interaction model (including moderating effects, referred to as Model 2) on the whole sample. The purpose of this approach is to test whether adding the interaction terms improves the explanatory power of the model. We apply the same process to both the direct effects and the interaction effects model (Chin et al., 2003). Table 4 displays the results of the PLS estimation for both models.

\section{<Please insert Table 4 about here>}

To test the mediating role of trust in the relationship between perceived value and loyalty, we examine and compare the results of Model 1 and Model 3 (trust is absent). Table 4 illustrates that trust mediates the value-loyalty relationship. As suggested by Baron and Kenny (1986), we find that (a) perceived value has a positive effect on loyalty in the absence of trust (Model 3), (b) perceived value has a positive effect on trust (Model 1), (c) trust has a positive effect on loyalty (Model 1), and (d) the effect of perceived value on loyalty is reduced in the presence of trust (Model 1). We observe that trust partially mediates the value-loyalty relationship. We also calculated the indirect effect of value on loyalty at $0.52(\mathrm{p} \leq 0.001)$. Following Falk and Miller $(1992)$, we then calculated the Variance Accounted For (VAF). Our VAF value of 0.501 indicates that just over half of the total effect (i.e., the sum of the indirect effect and the direct effect) is explained by the indirect effect. Finally, we control the model findings for the potential 
effects of consumer income and find that income does not have a significant effect on loyalty (see Table 4).

\section{Discussion of results}

We can observe that the structural model explains a satisfactory amount of variance of loyalty with high $\mathrm{R}^{2}$ values. Similarly, the Stone-Geisser criterion suggests that all models are of satisfactory predictive relevance, given that the $\mathrm{Q}^{2}$ values are above zero. Furthermore, when examining the models' goodness of fit (GoF) scores (i.e., the geometric mean of the average communality and the average $\mathrm{R}^{2}$ (Tenenhaus, Vinzi, Chatelin, \& Lauro, 2005)), it is clear that the model meets the criterion suggested by Ringle, et al. (2009) of a GoF of 0.5 being appropriate, and accordingly that the model displays good fit in relation to the data.

The favorable results of the assessment of the measurement and structural models render an interpretation of the models' relationships possible. The actual structural relationships as indicated by the path coefficients and their implications in terms of our research question are discussed below. With respect to the direct effects model (Model 1 in Table 3), we find significant positive paths for all relationships. The effect sizes $f^{2}$ display strong positive effects. These results support our theoretical reasoning summarized in hypotheses 1 and 2.

Following Harris and Goode (2004) we hypothesized that perceived value is positively related to trust $(\mathrm{H} 1)$. Our results strongly confirm this supposition $(\beta=.61)$. 
The results provide evidence for the mediating role of trust between perceived value and loyalty hypothesized in $\mathrm{H} 2$.

Overall, the findings support the view that perceived value and loyalty are significantly related (Bolton \& Drew, 1991; Chang \& Wildt, 1994; Cronin et al., 2000; Harris \& Goode, 2004; Peterson, Balasubramanian, \& Bronnenberg, 1997; Sirdeshmukh et al., 2002) and their relationship is mediated by trust (Harris \& Goode, 2004). Therefore, in line with the literature (Harris \& Goode, 2004; Reichheld \& Schefter, 2000; Sirdeshmukh et al., 2002), perceived value and trust are essential antecedents of loyalty.

Testing $\mathrm{H} 3$ and $\mathrm{H} 4$, we find that three out of four of the moderating effects of relationship age and usage level on perceived value-trust and trust-loyalty links are insignificant, with extremely small effect sizes. Therefore, our data does not support the notion that relationship age $(\mathrm{H} 3)$ or usage level $(\mathrm{H} 4)$ have moderating effects on perceived value-trust-loyalty links.

The results concerning the moderating effect of relationship age and usage level on perceived value-trust-loyalty paths offer important insights into customer relationship management in the telecommunications sector. We find slight support for the reversed effect of relationship age on the perceived value-trust link $(\beta=-.10, p \leq .05)$. This finding shows that the effect of perceived value on trust is time-dependent but the effect is reversed, and we therefore reject hypothesis 3 . In comparison to studies examining the moderating effect of relationship age on trust-loyalty paths, our results, in line with the literature (Raimondo et al., 2008), confirm that relationship age does not moderate the trust-loyalty path. In other words, the effect of trust on loyalty is not time-dependent. 
We did not observe a significant moderating effect of usage level on the perceived value-loyalty paths $(\mathrm{H} 4)$. This finding questions the view that customer loyalty is dependent on usage level. The common view that loyal customers spend more with a firm is at odds with our study findings. As such our findings mirror those of Reinartz and Kumar (2000; 2002), who question the positive link between expenditure (in terms of revenue and profit) and loyalty.

\section{Conclusion}

This study develops a model to explore the mediating role of trust between value and loyalty by simultaneously investigating the effects of relationship age and usage level. Our study differs from most previous value and loyalty research focusing on retailing or frequently-purchased consumer goods or services, in that it tests the relationships in a continuous service setting.

The first contribution of this research is to offer insights into the specifics of service dynamics and their influence on loyalty in a continuous service setting. Consistent with studies in other service contexts, perceived value and trust exhibit both direct and indirect associations with loyalty in a continuous service setting. Specifically, the current research shows that perceived value is a strong predictor of loyalty, and that trust mediates this process. Overall, our results provide empirical support to a number of existing studies that have emphasized the importance of examining, concurrently, a range of service variables including perceived value and trust (e.g., Harris \& Goode, 2004; Mathwick, Malhotra, \& Rigdon, 2002; Szymanski \& Hise, 2000; Zeithaml, Parasuraman, 
\& Malhotra, 2002). According to our findings, trust is important in building loyalty and should be incorporated into models examining loyalty in the context of the provision of continuous services.

The second contribution of the study relates to the examination of whether the effect of perceived value on loyalty is time dependent. We expected relationship age to strengthen perceived value-loyalty links, but our findings do not support the view that in longer relationships in the telecommunications sector, customer and supplier develop an increasing closeness similar to that found in non-contractual settings (Dwyer et al., 1987; Grayson \& Ambler, 1999; Jap, 1999). This finding is notable, as previous studies do not report relationship age as having a weakening effect on loyalty. Two previous studies in continuous service settings do partly support our findings, indicating relationship age has no significant effect on satisfaction in the insurance and financial services sectors either, where customer relationships are often 10 years long (Verhoef et al., 2002). Raimondo et al. (2008) also report findings from the Italian mobile telephone services sector that partially support our own. Thus, the non-significant effect of relationship age seems to be related to continuous services, while significant effects of relationship age have been reported in other fields.

We may speculate on a number of reasons for this counter-intuitive finding. First, it might be that the subscription relationship becomes a habit, and consequently most customers are only spuriously loyal and vulnerable to competing offerings as soon as the contract ends. At an industry level, telecommunications services have low switching costs, products are not differentiated, and true loyalty programs are scarce. 
Second, in most instances significant deals are heavily promoted to attract new customers, thus making existing customers question the wisdom of remaining loyal. According to Lai, Griffin, and Babin (2009), such practices are quite common in competitive mobile markets including those of the USA, Europe and China. In fact, it seems virtually all marketing in Finland is currently targeted at acquiring new customers. Such practices are not very conducive to building long-term trust. Third, unlike other continuous service providers, telecommunications service providers have less personal contact with customers and have fewer opportunities to build trust through positive service encounters. When combined, these reasons may explain why length of customer relationship does not enhance value-loyalty links.

Comparing relationship age in telecommunications services with research conducted in other countries (China: Lai et al., 2009; Korea: Kim, Park, \& Jeong, 2004; USA: Bolton, 1998) indicates that a significant proportion of customers in telecommunications service research are long-term customers with a relationship with a specific provider spanning around three years. Our findings then suggest that, in a continuous service setting, it does not matter if a person has been a customer for one, two, three or more years because the customer perception is that there are no significant rewards for loyalty.

As a third contribution, we offer new insights into the role of usage level. We expected the usage level to moderate the perceived value-loyalty links, with higher spending customers displaying stronger perceived value-loyalty links. Our findings indicate that the level of usage, as expressed by monthly expenditure, has no influence on the perceived value-loyalty links. Here again this counter-intuitive finding contrasts with 
the previous literature on the retail sector (Knox \& Denison, 2000), service sector (Reichheld \& Sasser, 1990; Reichheld, 1996), and telecommunications sector in particular (Ahn et al., 2006; Keramati \& Ardabili, 2011), which suggests that consumers who spend more with an organization are more loyal to it. However, this particular finding of the current study is in line with the studies conducted by Reinartz and Kumar (2000; 2002), who did not find a positive significant relationship between expenditure (in terms of revenue and profit) and loyalty. One potential explanation for this may be that over $80 \%$ of the study respondents reported having a monthly bill of less than 40 EUR. Therefore, fewer than $20 \%$ of the respondents were what might be termed heavy users. In addition, as the markets have evolved from pure price competition and easier switching, the service has become more uniform, and equally it appears that there are fewer differences between expenditure groups.

\subsection{Managerial implications}

In saturated mobile markets, the best core marketing strategy for the future would be to try to retain existing customers by strengthening customer loyalty and increasing customer value. The results of the study have a number of implications for service providers. The first being that our results reiterate the importance of value. Perceived value is instrumental in developing trust and drives loyalty. Service providers should appreciate that perceived value has both direct and indirect associations with loyalty. Providing a competent service (perceived value) can be instrumental in attracting 
customers in the first instance, and we have shown that it can be an extremely useful strategy to enhance customer loyalty.

Second, the fact that the length of a customer's relationship with the service provider has no bearing on the value-loyalty link should perhaps persuade service providers to offer long-standing customers demonstrable benefits or premium-value services that improve incrementally. As perceived value is a strong driver of loyalty such a strategy will promote a "sense of exclusivity" for loyal customers, and the associated benefits would accrue to the firm. Gerpott et al. (2001) posit that once customers have been acquired and connected to the telecommunications network of a particular operator, their long-term links with the focal operator are of greater importance to the success of the company in competitive markets than is the case in other industry sectors. In contrast, the findings of this study suggest that the length of the relationship is not relevant in a telecommunications service setting, even though it may be in other fields. This may be a result of the use of customer-club memberships in the telecom industry, which do not add value or contribute to higher commitment or loyalty, as was reported by Gustafsson, Roos, and Edvardsson (2004). Hence, new types of benefits should be offered to current customers to incentivize long-term commitment. Instead of following the current industry practice of locking in customers by imposing constraints on switching providers, companies should improve service (Eshghi, Haughton, \& Topi, 2007).

Intuitively we might assume that customers who spend more with suppliers are in turn more loyal. Hence, our finding that increasing levels of service usage inversely influence the trust-loyalty link (albeit a weak relationship) is perhaps surprising and we believe it is an area that practitioners should examine closely. It seems that the main 
reasons for the lack of significance of expenditure are that the telecommunications industry lacks value-added loyalty programs compounded by the fact that products are not well differentiated and switching costs are low. Perhaps, high-end users of a telecommunications service expect more trustworthy service. They are also more likely to encounter problems with the service, and the reduced trust they display may be caused by the service provider failing to meet its obligation to resolve service issues. It is in the interests of service providers to identify the heavy users of their service and dedicate more resources to serving them, specifically by ensuring that service problems are addressed satisfactorily and secondly by ensuring that the firm meets its obligations in full.

Service firms offering ongoing contracts should appreciate that, generally, longstanding customers with high monthly expenditure constitute the most profitable customer segment for a service firm. However, we would encourage telecommunications service providers to ultimately reduce their subscribers' price sensitivity, by building trust, especially with new customers in the early stages of the customer relationship, and by delivering better value to long-standing customers through enhanced levels of service.

\subsection{Limitations and further research}

The results of this study provide a foundation for the understanding of the drivers of customer loyalty in the continuous services sector. However, in considering any research, it is important to evaluate its limitations. We have identified four specific limitations of the study. First, in order to gain a deeper understanding of consumers in 
new markets, it would have been useful to consider other potential moderators, such as culture, that could influence service evaluation models. The effects of relationship age may be culture dependent, as Bartikowski, Walsh, and Beatty (2011) postulate that there are differences between British, American, and French customers concerning their willingness to form long-term customer relationships. Hence, future studies would benefit from conducting cross-cultural comparisons.

Second, our study is based upon a cross-sectional analysis, and as such, any relationships between constructs are based on theory rather than mathematical formulae, especially with regard to perceptions of causality amongst the variables included in our model.

Third, we measure all constructs in our study with a single survey conducted concurrently. Although our survey design minimizes the common method variance problem (e.g., all constructs are separated and the order is mixed) and we find no evidence of it in our data analysis (reliability and validity tests) its impact could only be completely ruled out if we had been able to collect data from different sources or through a longitudinal survey. Finally, the metric for expenditure is as perceived by the customers, not a measure of true expenditure validated by billing records.

Fourth, as Anderson and Simester (2004) argue, studies where naturally occurring data are used (such as relationship age) may suffer from endogeneity, if the independent variable is correlated with the error term in an OLS regression model. Therefore, it would be beneficial for future researchers to take extra care in selecting variables that are supposed to affect a particular outcome, themselves depend on that outcome. That would 
mean that researchers analyzing continuous customer relationships should ideally use measures of relationship age that are based on true behavior or self-reported relationship length data that truly depend on how loyal informants are to the company. Furthermore, researchers should ensure that there are no other factors that bias the relationship age, such as mergers and acquisitions of telecommunications operators.

The implications and limitations of this study provide directions for further research in this area. The findings should generalize to other continuously provided services. However, other cross-sectional studies will be necessary to investigate the influence of relationship age and consumption levels on perceived value-loyalty links. Further inquiry into the nature and dynamics of trust is also warranted. With some notable exceptions, the centrality of the concept within service dynamics literature understates, overlooks, or ignores trust. Future studies could profit from a re-evaluation of the concept and the position of trust within extant frameworks, models, and theories. 


\section{REFERENCES}

Agustin, C. \& Singh, J. (2005). Curvilinear effects of consumer loyalty determinants in relational exchanges. Journal of Marketing Research, 42 (February), 96-108.

Ahn, J.-H., Han, S.-P., \& Lee, Y.-S. (2006). Customer churn analysis: Churn determinants and mediation effects of partial defection in the Korean mobile telecommunications service industry. Telecommunications Policy, 30 (10-11), 552-568.

Armstrong, J. S., \& Overton, T. S. (1977). Estimating nonresponse bias in mail surveys. Journal of Marketing Research, 16 (August), 396-402.

Anderson, E. T., \& Simester, D. I. (2004). Long-run effects of promotion depth on new versus established customers. Marketing Science. 23 (1), 4-20.

Aydin, S., \& Özer, G. (2006). How switching costs affect subscriber loyalty in the Turkish mobile phone market: An exploratory study. Journal of Targeting, Measurement and Analysis for Marketing, 14 (January), 141-155.

Babin, L. A., \& Burns, A. C. (1998). A modified scale for the measurement of communication-evoked mental imagery. Psychology and Marketing, 15 (3), 261-278.

Bandyopadhyay, S., \& Martell, M. (2007). Does attitudinal loyalty influence behavioral loyalty? A theoretical and empirical study. Journal of Retailing and Consumer Services, 14 (1), 35-44.

Baron, R., \& Kenny, D. A. (1986). The moderator-mediator variable distinction in social psychological research: Conceptual, strategic, and statistical considerations? Journal of Personality and Social Psychology, 51 (6), 1173-1182.

Bartikowski, B., Walsh, C., \& Beatty, S. E. (2011). Culture and age as moderators in the corporate reputation and loyalty relationship. Journal of Business Research, 64 (9), 966-972.

Bearden, W. O., \& Etzel, M. J. (1982). Reference group influence on product and brand purchase decisions. Journal of Consumer Research, 9 (September), 183-194.

Bearden, W. O., \& Netemeyer, R. G. (1999). Handbook of marketing scales. Thousand Oaks: Sage Publications.

Berry, L. L. (1995). Relationship marketing of services: Growing interest, emerging perspectives. Journal of the Academic of Marketing Science, 23 (Fall), 236-245.

Bhat, S., Burkhard, R., O'Donnell, K. A., \& Wardlow, D. L. (1998). Version 6.0.1, anyone? An investigation of consumer software upgrading behavior. Journal of Marketing Theory and Practice, 6 (2), 87-96.

Bolton, R. N. (1998). A dynamic model of the duration of the customer's relationship with a continuous service provider: The role of satisfaction. Marketing Science, 17 (1), 45-65.

Bolton, R. N., \& Drew, J. H. (1991). A longitudinal analysis of the impact of service changes on customer attitudes. Journal of Marketing, 55 (January), 1-9.

Bolton, R. N., Kannan, P. K., \& Bramlett, M. D. (2000). Implications of loyalty program membership and service experiences for customer retention and value. Journal of Academy of Marketing Science, 28 (Winter), 95-108.

Chang, T.-Z., \& Wildt, A. R. (1994). Price, product information, and purchase intention: An empirical study. Journal of the Academy of Marketing Science, 22 (Winter), 16-27.

Chaudhuri, A., \& Holbrook, M. B. (2001). The chain of effects from brand trust and brand affect to brand performance: The role of brand loyalty. Journal of Marketing, 65 (April), 81-93.

Chin, W. W. (1998). The partial least squares approach to structural equation modelling. In G. A. Marcoulides (Ed.), Modern methods in business research (pp. 295-304). NJ: Lawrence Erlbaum Associates.

Chin, W. W., Marcolin, B. L., \& Newsted, P. R. (2003). A partial least squares latent variable modeling approach for measuring interaction effects: Results from a Monte Carlo simulation study and an electronic-mail emotion/adoption study. Information Systems Research, 14 (2), 189-217.

Chiou, J.-S., Wu, L.-Y., \& Chuang, M.-C. (2010). Antecedents of retailer loyalty: Simultaneously investigating channel push and consumer pull effects. Journal of Business Research, 63, 431-438.

Chiou, J.-S., \& Droge, C. (2006). Service quality, trust, specific asset investment, and expertise: Direct and indirect effects in a satisfaction-loyalty framework. Journal of the Academy of Marketing Science, 34 (4), 613-627. 
Cool, K., Dierickx, I., \& Jemison, D. (1989). Business strategy, market structure and risk-return relationships: A structural approach. Strategic Management Journal, 10 (6), 507-522.

Cronin, J. J. Jr., Brady, M. K., \& Hult, G. T. M. (2000). Assessing the effects of quality, value, and customer satisfaction on consumer behavioral intentions in service environments. Journal of Retailing, 76 (2), 193-218.

Crosby, L. A., Evans, K. R., \& Cowles, D. (1990). Relationship quality in services selling: An interpersonal influence perspective. Journal of Marketing, 54 (July), 68-81.

Dick, A. S., \& Basu, K. (1994). Customer loyalty: Toward an integrated conceptual framework. Journal of the Academy of Marketing Science, 22 (2), 99-113.

Doney, P. M., \& Cannon, J. P. (1997). An examination of the nature of trust in buyer-seller relationships. Journal of Marketing, 61 (April), 35-51.

Douglas, C. S., \& Craig, S. P. (1983). International marketing research. Englewood Cliffs, NJ: PrenticeHall.

Dwyer, F. R., Schurr, P. H., \& Oh, S. (1987). Developing buyer-seller relationships. Journal of Marketing, 51 (April), 11-27.

Eshghi, A., Haughton, D., \& Topi, H. (2007). Determinants of customer loyalty in the wireless telecommunications industry. Telecommunications Policy, 31 (2), 93-106.

Evanschitzky, H., \& Wunderlich, M. (2006). An examination of moderator effects in the four-stage loyalty model. Journal of Service Research, 8 (4), 330-345.

Evanschitzky, H., Iyer, G. R., Plassmann, H., Niessing, J., \& Meffert, H. (2006). The relative strength of affective commitment in securing loyalty in service relationships. Journal of Business Research, 59, 1207-1213.

Falk R. F., \& Miller, N. B. (1992). A primer for soft modeling. Akron, Ohio: The University of Akron Press.

Finnish Communications Regulatory Authority (FICORA) (2011). Viestintämarkkinat Suomessa [in English: Telecommunications markets in Finland], Market Overview 1/2011.

Fornell, C., \& Bookstein, F. L. (1982). Two structural equation models: LISREL and PLS applied to consumer exit-voice theory. Journal of Marketing Research, 19 (November), 440-52.

Fornell, C., \& Cha, J. (1994). Partial Least Squares. In R. P. Bagozzi (Ed.), Advanced methods of marketing research (pp. 52-78). Cambridge: Blackwell.

Fornell, C., \& Larcker, D. F. (1981). Evaluating structural equation models with unobservable variables and measurement error. Journal of Marketing Research, 18 (February), 39-50.

Garbarino, E., \& Johnson, M. S. (1999). The different roles of satisfaction, trust, and commitment in customer relationships. Journal of Marketing, 63 (April), 70-87.

Gerpott, T. T., Rams, W., \& Schindler, A. (2001). Customer retention, loyalty, and satisfaction in the German mobile cellular telecommunications market. Telecommunications Policy, 25, 249-269.

Grayson, K., \& Ambler, T. (1999). The dark side of long-term relationships in marketing services. Journal of Marketing Research, 36 (February), 132-141.

Gruen, T. W., Summers, J. O., \& Acito, F. (2000). Relationship marketing activities, commitment, and membership behaviours in professional association. Journal of Marketing, 64 (July), 34-49.

Gummerus, J., Liljander, V., Pura, M., \& van Riel, A. (2004). Customer loyalty to content based web sites. The case of an online health care site. Journal of Services Marketing, 18 (3), 175-186.

Gustafsson A., Roos, I., \& Edvardsson, B. (2004). Customer clubs in a relationship perspective: A telecom case. Managing Service Quality, 14 (2/3), 157-168.

Gwinner, K. P., Gremler, D. D., \& Bitner, M. J. (1998). Relational benefits in service industries: The customer's perspective. Journal of the Academy of Marketing Science, 26 (Spring), 101-114.

Hair, J., Anderson, R. E., Tatham, R. L. R., \& Black, W. C. (1998). Multivariate data analysis. (5th ed.). NJ: Prentice Hall.

Harman, H. H. (1967). Modern factor analysis. ( $2^{\text {nd }}$ ed.). Chicago: University of Chicago Press.

Harris, L. C., \& Goode, M. M. H. (2004). The four levels of loyalty and the pivotal role of trust: A study of online service dynamics. Journal of Retailing, 80 (2), 139-158.

Hennig-Thurau, T., Henning, V., \& Sattler, H. (2007). Consumer file sharing of motion pictures. Journal of Marketing, 71 (October), 1-18.

Hoffman, D. L., Novak, T. P., \& Peralta, M. A. (1999). Building consumer trust in online environments: The case for information privacy. Communications of the ACM, 42 (4), 80-85. 
Holbrook, M. B. (1994). The nature of customer value: An axiology of services in the consumption experience. In R. T. Rust, \& R. L. Oliver (Eds.), Service quality: New directions in theory and practice (pp. 21-71). Newbury Park, CA: Sage.

Homburg, C., \& Pflesser, C. (2000). A multiple-layer model of market-oriented organizational culture: Measurement issues and performance outcomes. Journal of Marketing Research, 37 (4), 449-462.

Jacoby, J., \& Chestnut, R. W. (1978). Brand loyalty: Measurement and management. New York: John Wiley \& Sons.

Jap, S. D. (1999). Pie-expansion efforts: Collaboration processes in buyer-supplier relationships. Journal of Marketing Research, 36 (November), 461-475.

Johnson, M. D., Herrmann, A., \& Huber, F. (2006). The evolution of loyalty intentions. Journal of Marketing, 70 (April), 122-132.

Kalwani, M. U., \& Narayandas, N. (1995). Long-term manufacturer-supplier relationships: Do they pay off for supplier firms? Journal of Marketing, 59 (January), 1-16.

Keramati, A., \& Ardabili, S. M. S. (2011). Churn analysis for an Iranian mobile operator. Telecommunications Policy, 35 (4), 344-356.

Kim, B. (2012). The diffusion of mobile data services and applications: Exploring the role of habit and its antecedents. Telecommunications Policy, 36 (1), 69-81.

Kim, H.-S., \& Yoon, C.-H. (2004). Determinants of subscriber churn and customer loyalty in the Korean mobile telephony market. Telecommunications Policy, 28 (October-November), 751-765.

Kim, M.-K., Park, M.-C., \& Jeong, D.-H. (2004). The effects of customer satisfaction and switching barrier on customer loyalty in Korean mobile telecommunication services. Telecommunications Policy, 28, 145-159.

Knox, S. D., \& Denison, T. D. (2000). Store loyalty: Its impact on retail revenue. An empirical study of purchasing behaviour in the UK. Journal of Retailing and Consumer Services, 7 (1), 33-45.

Lai, F., Griffin, M., \& Babin, B. J. (2009). How quality, value, image, and satisfaction create loyalty at a Chinese telecom. Journal of Business Research, 62, 980-986.

Lau, T. T., \& Lee, S. H. (1999). Consumers' trust in a brand and the link to brand loyalty. Journal of Market-Focused Management, 4 (4), 341-370.

Lee, J., Lee, J., \& Feick, L. (2001). The impact of switching costs on the customer satisfaction-loyalty link: Mobile phone service in France. Journal of Services Marketing, 15 (1), 35-48.

Liang, H., Saraf, N., Hu, Q., \& Xue, Y. (2007). Assimilation of enterprise system: The effect of institutional pressures and the mediating role of top management. MIS Quarterly, 31 (1), 59-87.

Little, R. J. A., \& Rubin, D. B. (1987). Statistical analysis with missing data. New York: John Wiley \& Sons.

Mathwick, C., Malhotra, N. K., \& Rigdon, E. (2002). The effect of dynamic retail experiences on experiential perceptions of value: An Internet and catalog comparison. Journal of Retailing, 78 (1), 51-60.

Morgan, R. M., \& Hunt, S. D. (1994). The commitment-trust theory of relationship marketing. Journal of Marketing, 58 (July), 20-38.

Mullen, M. R. (1995). Diagnosing measurement equivalence in cross-national research. Journal of International Business Studies, 26 (3), 573-596.

Oliver, R. L. (1997). Satisfaction: A behavioural perspective on the consumer. New York: McGraw Hill.

Oliver, R. L. (1999). Whence customer loyalty. Journal of Marketing, 63 (Special issue), 33-44.

Parasuraman, A, \& Grewal, D. (2000). The impact of technology on the quality-value-loyalty chain: A research agenda. Journal of the Academy of Marketing Science, 28 (1), 168-174.

Peterson, R. A., Balasubramanian, S., \& Bronnenberg, B. J. (1997). Exploring the implications of the Internet for consumer marketing. Journal of the Academy of Marketing Science, 25 (4), 329-346.

Podsakoff, P. M., MacKenzie, S. B., Lee, J.-Y., \& Podsakoff,N. P. (2003). Common method biases in behavioral research: A critical review of the literature and recommended remedies. Journal of Applied Psychology, 88 (5), 879-903.

Raimondo, M. A., Gaetano, M., \& Costabile, M. (2008). How relationship age moderates loyalty formation: The increasing effect of relational equity on customer loyalty. Journal of Service Research, 11 (2), 142-160.

Reichheld, F. F. (1996). The loyalty effect. Boston, MA: Harvard Business School Press.

Reichheld, F. F., \& Sasser, W. E. Jr. (1990). Zero defects: Quality comes to service. Harvard Business Review, 68 (October), 105-111. 
Reichheld, F. F., \& Schefter, P. (2000). E-loyalty: Your secret weapon on the Web. Harvard Business Review, 78 (July), 105-113.

Reinartz, W. J., \& Kumar, V. (2000). On the profitability of long-life customers in a noncontractual setting: An empirical investigation and implications for marketing. Journal of Marketing, 64 (October), 1735 .

Reinartz, W. J., \& Kumar, V. (2002). The mismanagement of customer loyalty. Harvard Business Review, 80 (July), 86-94.

Reynolds, J. (2000). E-commerce: A critical review. International Journal of Retail and Distribution Management, 28 (10), 417-444.

Ringle, C., Wende, S., \& Will, A. (2005). Smart-PLS version 2.0 M3, [available at http://www.smartpls.de].

Ringle, C. M., Wende, S., \& Will, A. (2009). The finite mixture partial least squares approach: Methodology and application. In V. E. Vinzi, W. W. Chin, J. Henseler, \& H. Wang (Eds.), Handbook of partial least squares: Concepts, methods and applications in marketing and related fields. Berlin: Springer.

Sanchez-Fernandez, R., \& Iniesta-Bonillo, M. A. (2007). The concept of perceived value: A systematic review of research. Marketing Theory, 7 (4), 427-451.

Sheth, J. N., Newman, B. I., \& Gross, B. L. (1991a). Why we buy what we buy: A theory of consumption values. Journal of Business Research, 22 (2), 159-170.

Sheth, J. N., Newman, B. I., \& Gross, B. L. (1991b). Consumption values and market choices. Theory and applications. Cincinnati, OH: South-Western Publishing Co.

Singh, J., \& Sirdeshmukh, D. (2000). Agency and trust mechanisms in consumer satisfaction and loyalty judgments. Journal of the Academy of Marketing Science, 28 (1), 150-168.

Sirdeshmukh, D., Singh, J., \& Sabol, B. (2002). Consumer trust, value, and loyalty in relational exchanges. Journal of Marketing, 66 (January), 15-37.

Srinivasan, S. S., Anderson, R., \& Ponnavolu, K. (2002). Customer loyalty in e-commerce: An exploration of its antecedents and consequences. Journal of Retailing, 78 (1), 41-50.

Stewart, K. J. (2003). Trust transfer on the World Wide Web. Organization Science, 14 (1), 5-17.

Swann, W. B. Jr., \& Gill, M. J. (1997). Confidence and accuracy in person perception: Do we know what we think we know about our relationship partners? Journal of Personality and Social Psychology, 73 (4), 747-757.

Sweeney, J. C., \& Soutar, G. N. (2001). Customer perceived value: The development of a multiple item scale. Journal of Retailing, 77 (2), 203-220.

Szmigin, I., \& Bourne, H. (1998). Consumer equity in relationship marketing. Journal of Consumer Marketing, 15 (6), 544-557.

Szymanski, D. M., \& Hise, R. T. (2000). E-satisfaction: An initial examination. Journal of Retailing, 76 (3), 309-322.

Tenenhaus, M., Vinzi, V. E., Chatelin, Y.-M., \& Lauro, C. (2005). PLS path modeling. Computational Statistics \& Data Analysis, 48, 159-205.

Verhoef, P. C. (2003). Understanding the effect of customer relationship management efforts on retention and customer share development. Journal of Marketing, 67 (October), 30-45.

Verhoef, P. C., Francis, P. H., \& Hoekstra, J. C. (2002). The effect of relational constructs on customer referrals and number of services purchased from multiservice provider: Does age of relationship matter? Journal of the Academy of Marketing Science, 30 (3), 202-216.

Verhoef, P. C., Francis, P. H., \& Hoekstra, J. C. (2001). The impact of satisfaction and payment equity on cross-buying: A dynamic model for a multi-service provider. Journal of Retailing, 77 (3), 359-378.

Wang, Y., Lo, H. P., Chi, R., \& Yang, Y. (2004). An integrated framework for customer value and customer-relationship management performance: A customer-based perspective from China. Managing Service Quality, 14 (2/3), 169-182.

Yung, Y.-F., \& Bentler, P. M. (1996). Bootstrapping techniques in analysis of mean and covariance structures. In G. A. Marcoulides, \& R. E. Schumacker (Eds.), Advanced structural equation modelling: Issues and techniques (pp. 195-226). Mahwah: Erlbaum.

Zaichowsky, J. L. (1985). Measuring the involvement construct. Journal of Consumer Research, 12 (December), 341-352.

Zeithaml, V. A., Berry, L. L., \& Parasuraman, A. (1996). The behavioral consequences of service quality. Journal of Marketing, 60 (April), 31-46. 
Zeithaml, V. A., Parasuraman, A., \& Malhotra, A. (2002). Service quality delivery through Web sites: A critical review of extant knowledge. Journal of the Academy of Marketing Science, 30 (4), 362375. 


\section{LIST OF FIGURES}

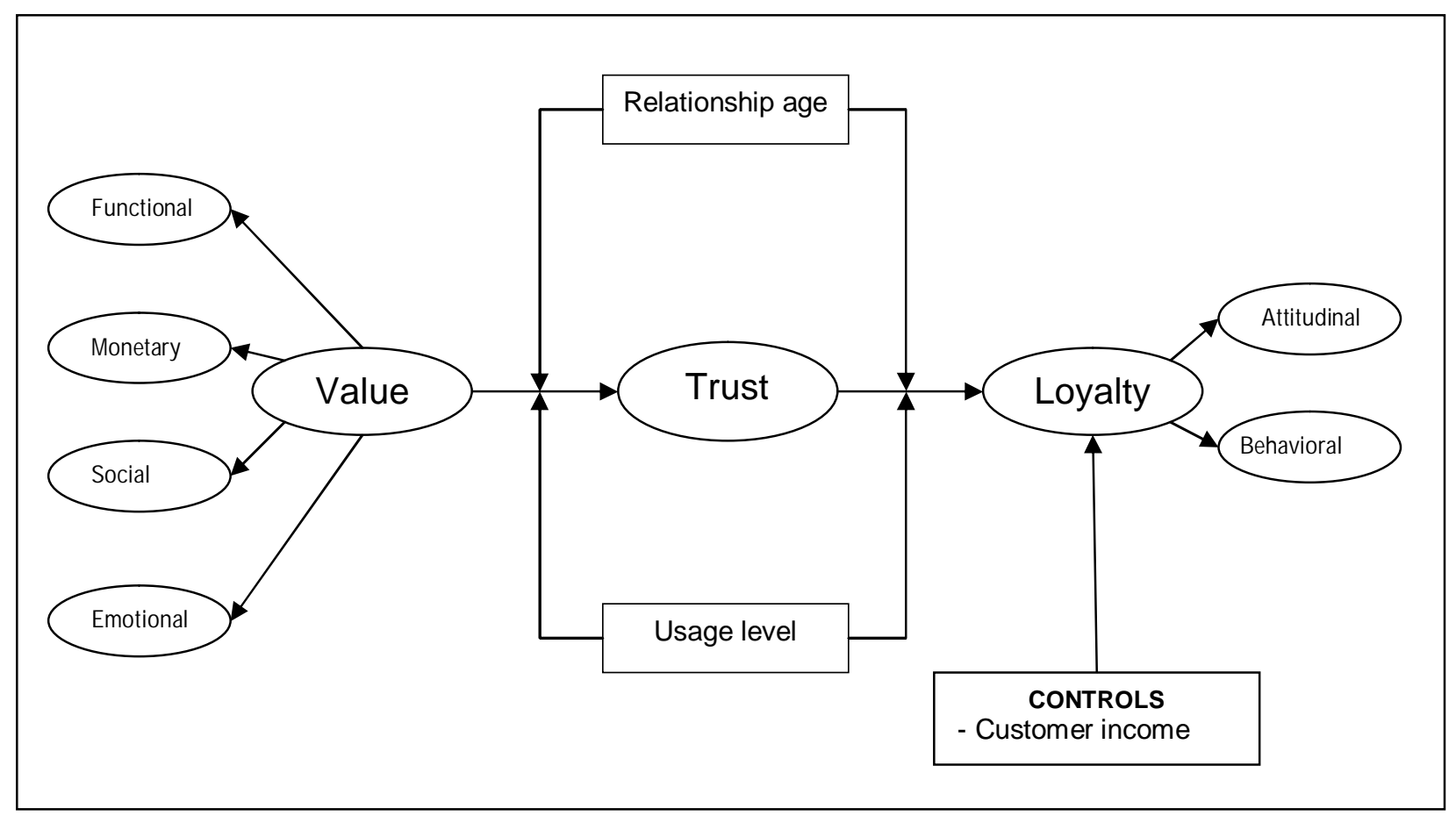

Figure 1: Conceptual Model 


\section{LIST OF TABLES}

\begin{tabular}{|l|c|c|}
\hline \multicolumn{1}{|c|}{ Descriptors } & Population & Sample \\
\hline$N$ & $5,375,276$ & 1,385 \\
\hline Gender & & \\
\hline Male (\%) & 49.1 & 43.7 \\
\hline Female (\%) & 50.9 & 56.3 \\
\hline Age & & \\
\hline $16-19(\%)$ & 6.1 & 1.8 \\
\hline $20-24(\%)$ & 6.1 & 9.2 \\
\hline $25-34(\%)$ & 12.8 & 19.1 \\
\hline $35-49(\%)$ & 19.4 & 31.3 \\
\hline $50-64(\%)$ & 21.6 & 35.8 \\
\hline 65 or more $(\%)$ & 17.5 & 2.9 \\
\hline Place of residence & & \\
\hline Capital region $(\%)$ & 19.4 & 21.3 \\
\hline Large cities $(50,000+$ inhabitants) $(\%)$ & 28.5 & 32.5 \\
\hline Small cities \& countryside $(\%)$ & 52.1 & 46.2 \\
\hline Mobile phone subscription $(\%) *$ & Over 100.0 & Over 100.0 \\
\hline
\end{tabular}

Note: * Many Finns have two mobile phone contracts (private and work). In total the Finns have 8,400,000 mobile phone contracts.

Data for the Finnish population are from the Statistics Finland, available at http://www.stat.fi.

Table 1. Population and sample 


\begin{tabular}{|l|c|c|c|}
\hline & AVE & $\begin{array}{c}\text { Composite } \\
\text { Reliability (CR) }\end{array}$ & Cronbach's \\
& 0.583 & 0.933 & 0.920 \\
\hline Loyalty & 0.871 & 0.976 & 0.970 \\
\hline Relationship age * & & & \\
Trust & 0.671 & 0.957 & 0.951 \\
\hline Relationship age * & 0.785 & 0.956 & 0.945 \\
\hline Trust & 0.558 & 0.933 & 0.920 \\
\hline Value & & & \\
\hline
\end{tabular}

Table 2. Average variance extracted and reliabilities 


\begin{tabular}{|l|c|c|c|c|c|c|}
\hline & $\begin{array}{c}\text { Expenditu } \\
\text { re }\end{array}$ & Loyalt & Relationship & Trust & Value & e \\
\hline Expenditure & $\boldsymbol{n a}$ & & & & & \\
\hline Loyalty & -0.09 & $\mathbf{0 . 7 6}$ & & & & \\
\hline Relationship & 0.04 & 0.10 & $\boldsymbol{n a}$ & & & \\
age & & & & & & \\
\hline Trust & -0.10 & 0.56 & 0.07 & $\mathbf{0 . 8 9}$ & & \\
\hline Value & -0.11 & 0.67 & 0.03 & 0.66 & $\mathbf{0 . 7 5}$ & \\
\hline Income & 0.18 & -0.10 & 0.11 & -0.10 & -0.14 & $\boldsymbol{n a}$ \\
\hline
\end{tabular}

Table 3. Construct correlations and square root of AVE on the diagonal 


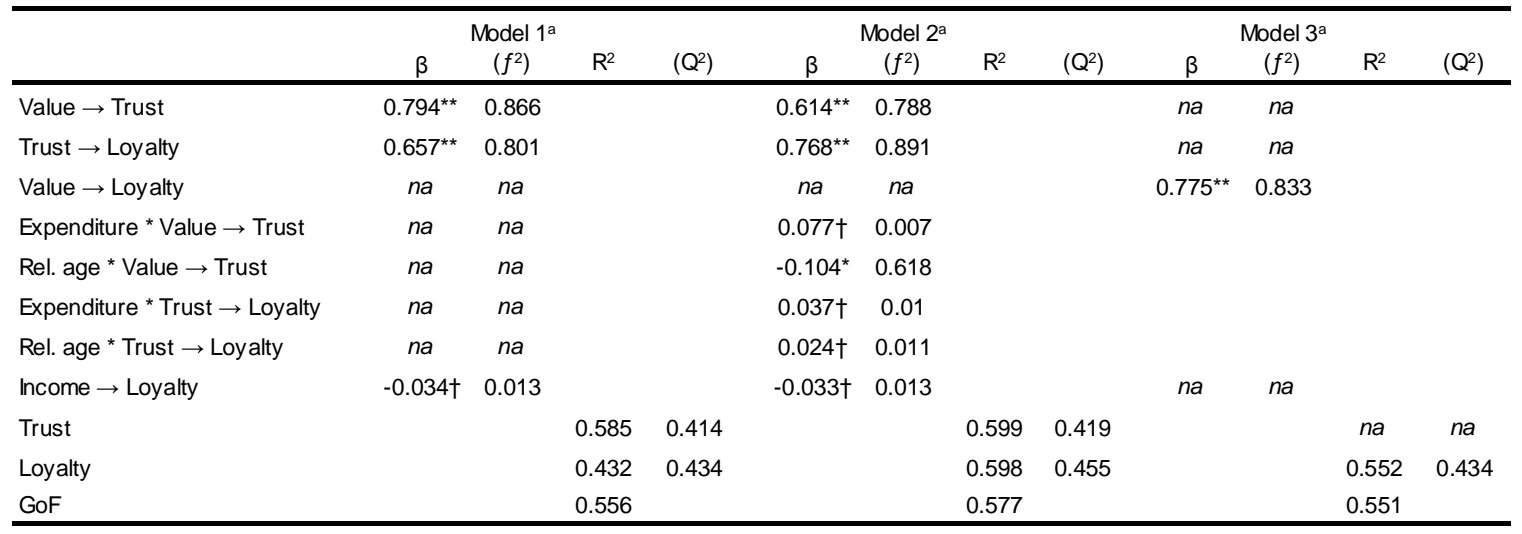

${ }^{* *} p \leq 0.001 ;{ }^{*} p \leq 0.05$; (one-sided test); $\uparrow$ - not significant

a - Model 1: Direct effects ( $w$ ith linear effect terms only); Model 2: Full Model ; Model 3: Comparison Model (no mediating effects of trust)

Table 4. Structural model(s) 